\title{
Development and Evaluation of a Hand Operated Double Chain-Sprocket Winnower for Cereal Crops
}

\author{
Anup Behera*, Arjya Utkalini Sahoo, Jyoti Ranjan Swain, \\ Suprava Kar and Markandeya Mahapatra
}

\author{
Department of Farm Machinery and Power, College of Agricultural Engineering and \\ Technology, Bhubaneswar, Odisha, India \\ *Corresponding author
}

\section{Keywords}

Anemometer, Double chainsprocket winnower, Drudgery, Energy expenditure, Pulse oximeter and Wind speed

\section{Article Info}

Accepted:

05 February 2020

Available Online:

10 March 2020
A double chain-sprocket winnower was developed to reduce the hand drudgery and increase the efficiency of the winnower. The winnower consisted of two stage chain and sprocket transmission system with an overall speed increment ratio of 6 . The performance and ergonomical evaluation of the developed winnower was carried out using anemometer and pulse oximeter, respectively. Both the evaluation parameters were compared with the pinion driven winnower and single chain-sprocket type winnower.The double chain sprocket developed highest wind speed with an average wind speed of $5.92 \mathrm{~m} / \mathrm{s}$ followed by pinion driven type winnower with an average wind speed of $4.66 \mathrm{~m} / \mathrm{s}$ and single chain sprocket type winnower with an average wind speed of $4.08 \mathrm{~m} / \mathrm{s}$. Further, the double chain sprocket required lowest energy expenditure with an average value of 13.23 $\mathrm{kJ} / \mathrm{min}$, whereas the energy required for single chain sprocket type and pinion driven type winnower was $15.76 \mathrm{~kJ} / \mathrm{min}$. and $17.38 \mathrm{~kJ} / \mathrm{min}$, respectively. The overall weight of the machine was only $23.5 \mathrm{~kg}$ and the production cost of the developed winnower was Rs. 4492 making it affordable for small and marginal

\section{Introduction}

Rice is the most consumable staple food crop of India. India is the second largest producer of rice after China with a production of 172.8 million metric ton and share a global production of more than $11 \%$ (Anonymous 2020). In financial year 2019, the rice yield was estimated as 2.6 thousand $\mathrm{kg} / \mathrm{ha}$ (Anonymous, 2020a). West Bengal, Uttar Pradesh, Andhra Pradesh, Punjab, Tamil Nadu, Odisha, and Bihar are the major rice producing states. In Odisha, rice area covers about70 \% of total cultivated area, 63 percent of total area under food grains and about $90 \%$ of area under cereals. In 2016-17, rice 
production was 9.79 metric ton in 3.96 million ha area with a productivity of 2471 $\mathrm{kg} / \mathrm{ha}$ (Anonymous 2019).

The harvesting of paddy is usually carried at quite high moisture content (25\%) to avoid loss of grains during harvesting. After harvesting, the crop is allowed to dry in the field and then tied in small bundles and carried to threshing yard (Anonymous, 2015). The grains are separated from the straw with a thresher or conventional local methods. To separate the threshed grains from chaff, winnowing operation is carried out.

Winnowing is the method of extracting grain from a mixture of grain and chaff in a naturally or artificially produced air stream. Separation is achieved by allowing the air stream to pass through the falling mixture vertically downwards. The grain being heavier material is deposited nearly at the dropping place, whereas lighter material (chaff) is blown away to a greater distance. Winnowing operation in India is performed on a threshing floor, where all harvested crops are stacked in bundles.

Traditionally, winnowing is carried out to separate straw or bhusa from the paddy by creating air draft or natural wind by dropping the grain from pan or scoop from a certain height in blowing wind. This is very simple and effective method, but output is very low, i.e., 40-45 kg/h (Singh and Gite, 2007). The existing hand winnowers like, pinion driven winnower and single chain sprocket winnower have low output capacity and are tedious for farm workers. So, to reduce the drudgery of hand winnowing and increase the efficiency of the winnowing machine, a double chain sprocket winnower was developed. The performance of the developed winnower was evaluated and ergonomical parameters were studied. The performance of the developed winnower was compared with pinion driven winnower and single chain sprocket winnower.

\section{Materials and Methods}

\section{Development of double chain sprocket winnower}

The CAD design and developed double chain sprocket winnower are shown in Figs. 1 and 2 , respectively. The lower frame had four legs to hold the upper part of Winnower. The frame was made up of MS angles of different dimensions which are welded together to form a sturdy joint. The lower frame should be properly oriented to give a stable stand to the Winnower. The upper frame was the main working part of the winnower as it carried all the working shafts, bearing blocks, sprockets and chain arrangements. Three $500 \mathrm{~mm}$ length fan blades were used for the winnower. The chain and sprockets arrangement is shown in Fig. 3.The fan assembly was connected to the $25 \mathrm{~mm}$ diameter output shaft on which the small sprocket of 18 numbers of teeth was bolted. A handle was connected to the $20 \mathrm{~mm}$ diameter input shaft on which the big sprocket of 44 numbers of teeth was bolted. In the bottom bearing blocks, a $20 \mathrm{~mm}$ diameter intermediate shaft was fitted on which one big and one small sprocket of 44 and 18numbers of teeth were bolted for the simultaneous rotation of both the sprockets. The working principle of the transmission is shown in Fig. 4. The winnower was provided with a fan guard in front of fan to prevent any accident. The overall weight of the developed winnower was $23.5 \mathrm{~kg}$.

In $1^{\text {st }}$ step up, increment of speed $=44 / 18$

In $2^{\text {nd }}$ step up, increment of speed $=44 / 18$

So, the overall increment of speed $=(44 / 18)^{2}$ $=5.97 \approx 6$ 


\section{Performance evaluation}

Aerodynamic properties of Wheat and Rice (paddy) are important factors in pneumatic conveying, separating and cleaning machines. Among all the physical properties, terminal velocity is very important. Terminal velocity was measured as the minimum air velocity at which the grains remained suspended in air. Therefore, the wind speed developed by the winnower (cleaning machine) should be less than the terminal velocity of grain and more than that of straw for efficient cleaning of the threshed grain. So, the wind speed developed by the double chain and sprocket winnower was measured using anemometer (Fig. 5). Also, the wind speed developed by the pinion driven winnower (gear ratio $=5$ ) and single chain sprocket winnower (gear ratio $=2.44$ ) was measured for comparison.

The wind speed of the three models were measured by 5 different worker groups i.e. 22 year male $\left(S_{22}\right), 22$ year female $\left(S_{22} F\right), 25$ year male $\left(S_{25}\right), 30$ year male $\left(S_{30}\right)$ and 42 year male $\left(\mathrm{S}_{42}\right)$ workers.

\section{Ergonomical evaluation}

The heart rate of the 5 different groups i.e. 22 year male $\left(S_{22}\right), 22$ year female $\left(S_{22} F\right), 25$ year male $\left(S_{25}\right), 30$ year male $\left(S_{30}\right)$ and 42 year male $\left(\mathrm{S}_{42}\right)$ workers was measured before and during operating for the three different type of winnowers using a pulse oximeter as shown in Fig. 6.

Heart rate or heart pulse, is the speed of the heartbeat measured by the number of poundings of the heart per unit of time; typically beats per minute (bpm).

The maximum heart rate $\left(\mathrm{HR}_{\mathrm{MAX}}\right)$ is the highest heart rate an individual can achieve without severe problems through exercise stress and generally decreases with age.
The maximum heart rate $\left(\mathrm{HR}_{\mathrm{MAX}}\right)$ was calculated using the following equation (Fox et al., 1971).

$\mathrm{HR}_{\text {MAX }}=220-$ age of the person

Where, $\mathrm{HR}_{\mathrm{MAX}}=$ Maximum heart rate, beats/min.

$$
\begin{aligned}
& \Delta \mathrm{HR}=\mathrm{HR}_{\text {work }}-\mathrm{HR}_{\text {rest }} \\
& \mathrm{HHR}_{\max }=\frac{\mathrm{HR}_{\text {work }}}{\mathrm{HR}_{\max }} \times 100
\end{aligned}
$$

Where, $\Delta H R=$ Net heart rate, beats $/ \mathrm{min}$.

$\mathrm{HR}_{\text {work }}=$ Heart rate during work, beats $/ \mathrm{min}$.

$\mathrm{HR}_{\text {rest }}=$ Heart rate at rest, beats/min.

$\% \mathrm{HR}_{\max }=$ Percentage of maximum heart rate, $\%$

Energy expenditure during work was calculated using the following equation (Singh and Gite, 2007).

$\mathrm{VO}_{2}=0.0155 \times(\mathrm{HR})-1.2248$

Where, $\mathrm{VO}_{2}=$ Oxygen consumption, $1 / \mathrm{min}$. $\mathrm{HR}=$ Heart rate, beats/min.

The oxygen consumption ( $1 / \mathrm{min})$ was converted in $\mathrm{kJ}$ ( 1 litre $\mathrm{O}_{2}=20.93 \mathrm{~kJ}$ ) for calculating energy expenditure.

\section{Results and Discussion}

\section{Performance evaluation}

Wind speed developed by three different type winnowers is shown in Fig. 7.From Fig. 7, it can be seen that for all the worker groups, a higher wind speed was observed with double chain sprocket type winnower compared to single chain sprocket type and pinion driven type winnower. For the same work effort, the double chain sprocket developed highest wind speed with an average wind speed of $5.92 \mathrm{~m} / \mathrm{s}$ 
followed by pinion driven type winnower with an average wind speed of $4.66 \mathrm{~m} / \mathrm{s}$ and single chain sprocket type winnower with an average wind speed of $4.08 \mathrm{~m} / \mathrm{s}$. The terminal velocity of paddy and paddy straw is $7.2 \mathrm{~m} / \mathrm{s}$ and 1.07-4.48 m/s, respectively (Gorialand O'callaghan, 1990 and Parkand Kim, 1998). Similarly, the terminal velocity of wheat and wheat straw is 8.8-9.2 $\mathrm{m} / \mathrm{s}$ and $4.9 \mathrm{~m} / \mathrm{s}$, respectively (Bilanskiand Lai, 1965). So, the double chain sprocket type winnower can efficiently remove the straw from grain for both paddy and wheat because its developed wind speed is higher than the terminal velocity of straw and less than the terminal velocity of grain for both the crops. However, the other two models can notremove wheat straw efficiently as the wind speed developed by them were less than the terminal velocity of wheat straw.

\section{Ergonomical evaluation}

The ergonomical data of the three different types of winnowers are given in table 1. From this table, it can be seen that for all worker groups, the $\mathrm{HR}_{\text {work }}$ was found to be minimum for double chain sprocket type compared to single chain sprocket type and pinion driven type winnower. The average $\mathrm{HR}_{\text {work }}$ for double chain sprocket type, single chain sprocket type and pinion driven type winnower were 119.8, 127.6 and 132.6 beats/min. respectively.

Similarly, the $\mathrm{VO}_{2}$ and energy expenditure were found to be minimum for double chain sprocket type compared to single chain sprocket type and pinion driven type winnower for all work groups. The double chain sprocket required lowest energy expenditure with an average value of 13.23 $\mathrm{kJ} / \mathrm{min}$. At the same time, energy requirement for single chain sprocket type and pinion driven type winnower was $15.76 \mathrm{~kJ} / \mathrm{min}$. and $17.38 \mathrm{~kJ} / \mathrm{min}$, respectively.

Fig.1 CAD design of the double chain sprocket winnower

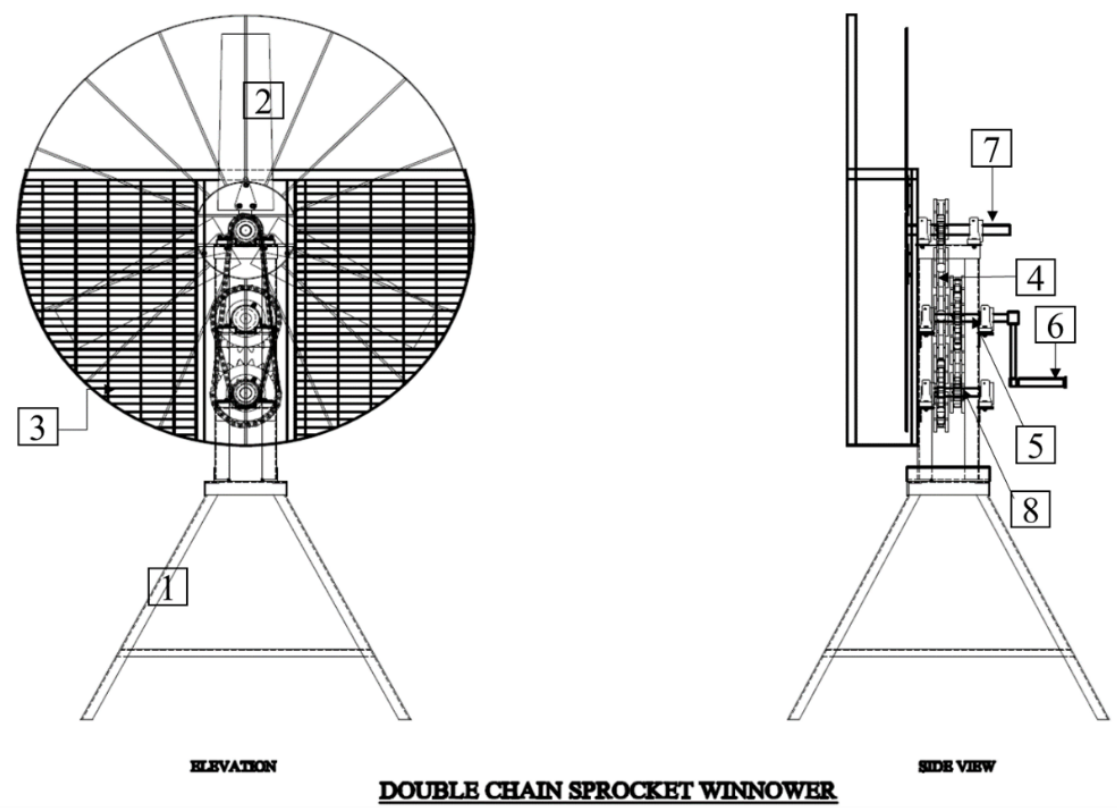

1. Lower Frame, 2. Fan blade, 3. Fan guard, 4. Double chain and sprocket transmission system, 5. Input shaft, 6. Handle, 7. Output shaft, 8. intermediate shaft 
Fig.2 Developed double chain sprocket winnower

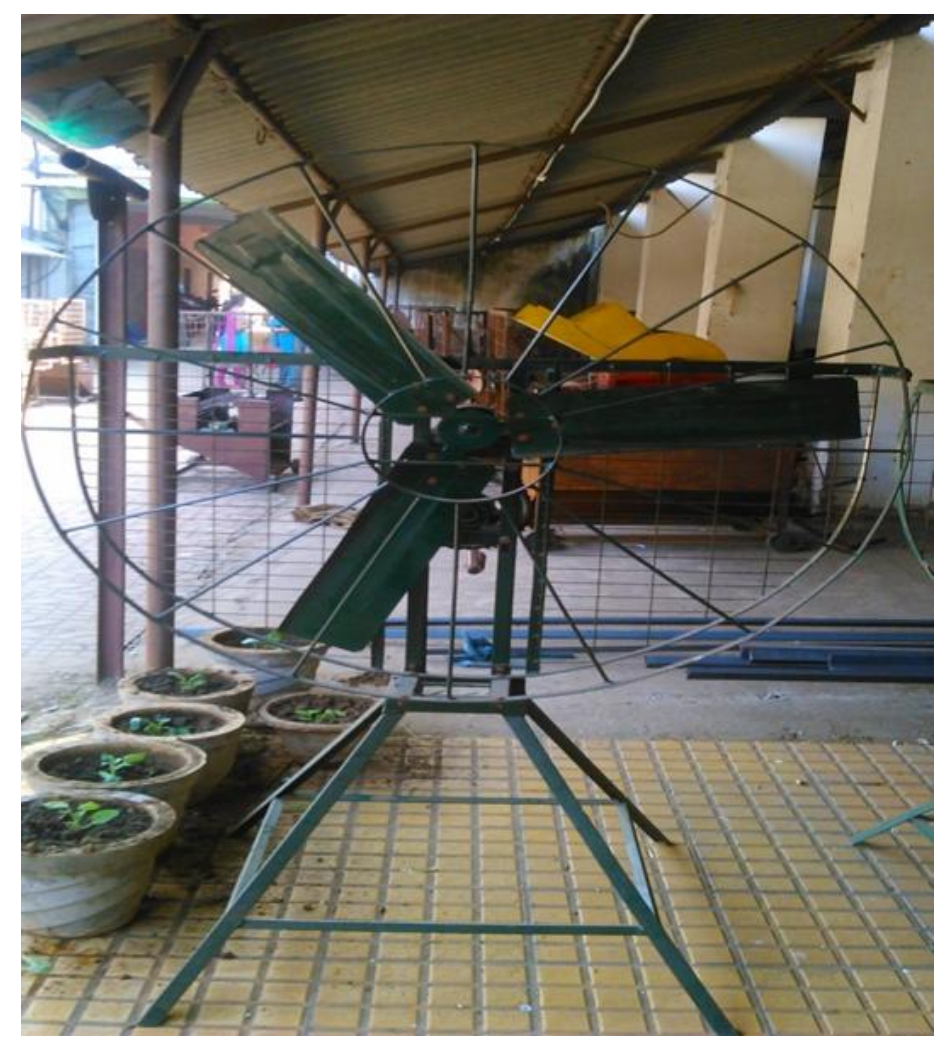

Fig.3 Double chain and sprocket transmission system

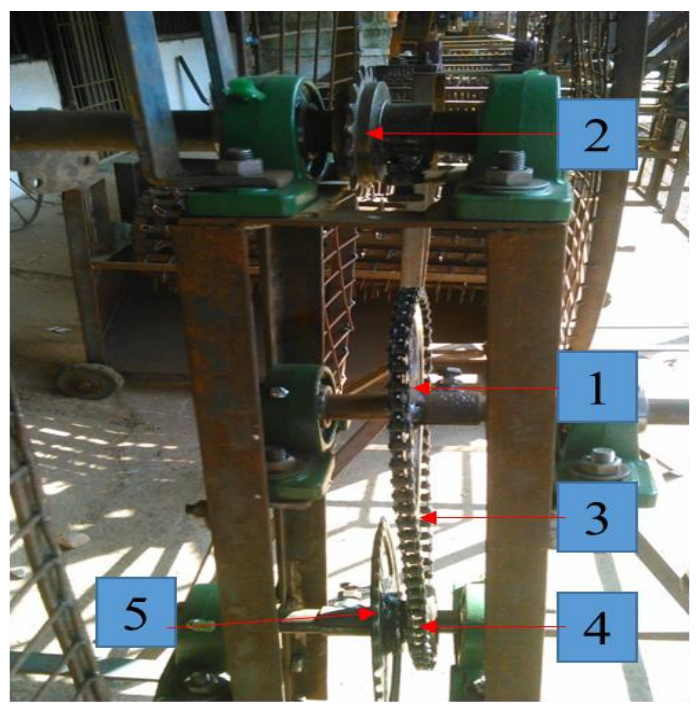

Side view

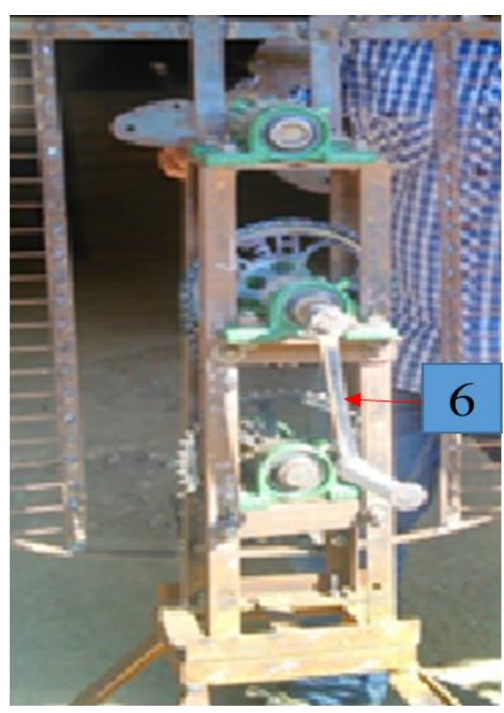

Front view

1. Big sprocket of input shaft, 2. Small sprocket of output shaft, 3. Chain drive, 4. Small sprocket of intermediate shaft, 5. Big sprocket of intermediate shaft, 6 . Handle 
Fig.4 Principle of working of double chain and sprocket transmission system

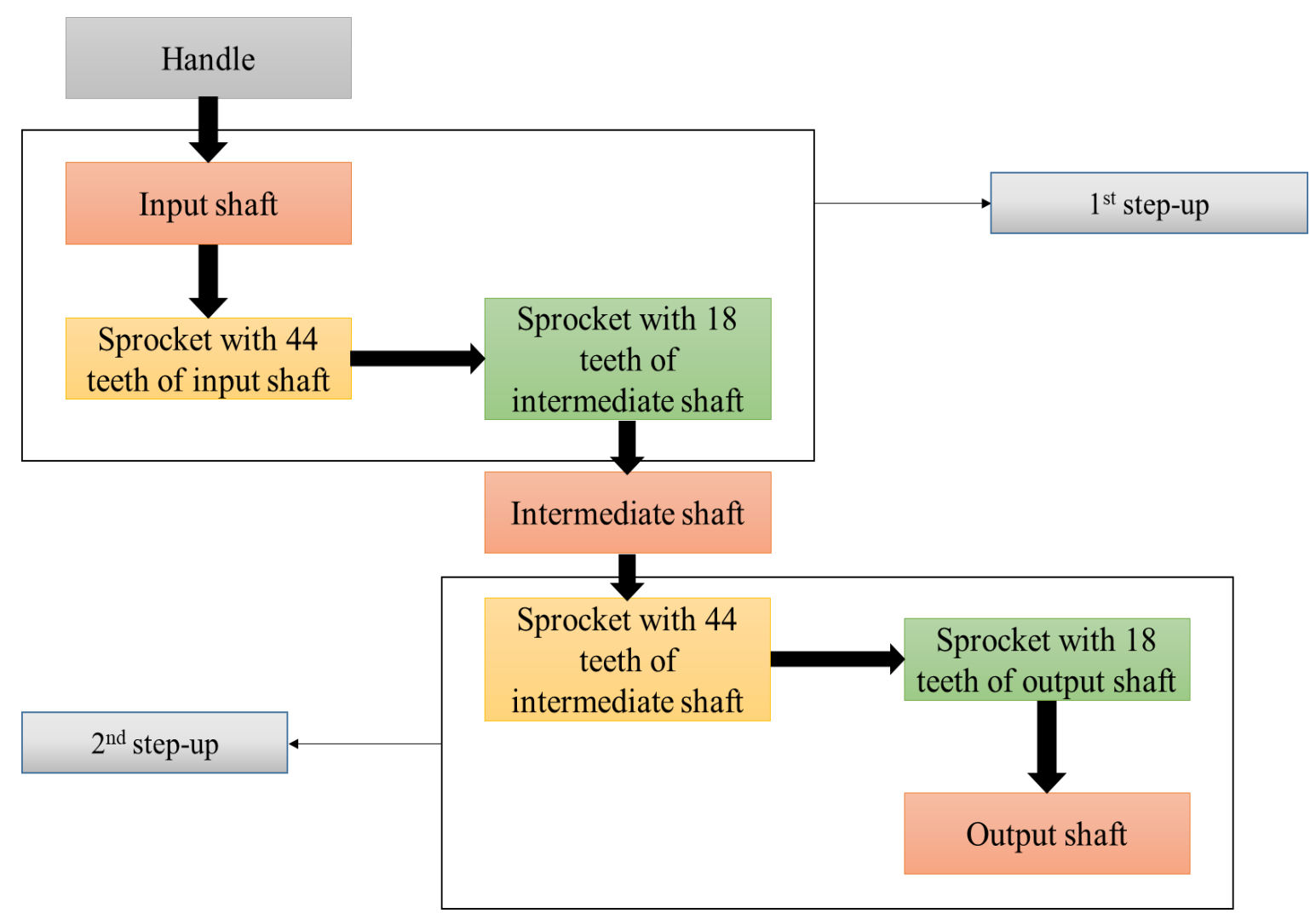

Fig.5 Measurement of wind speed using anemometer
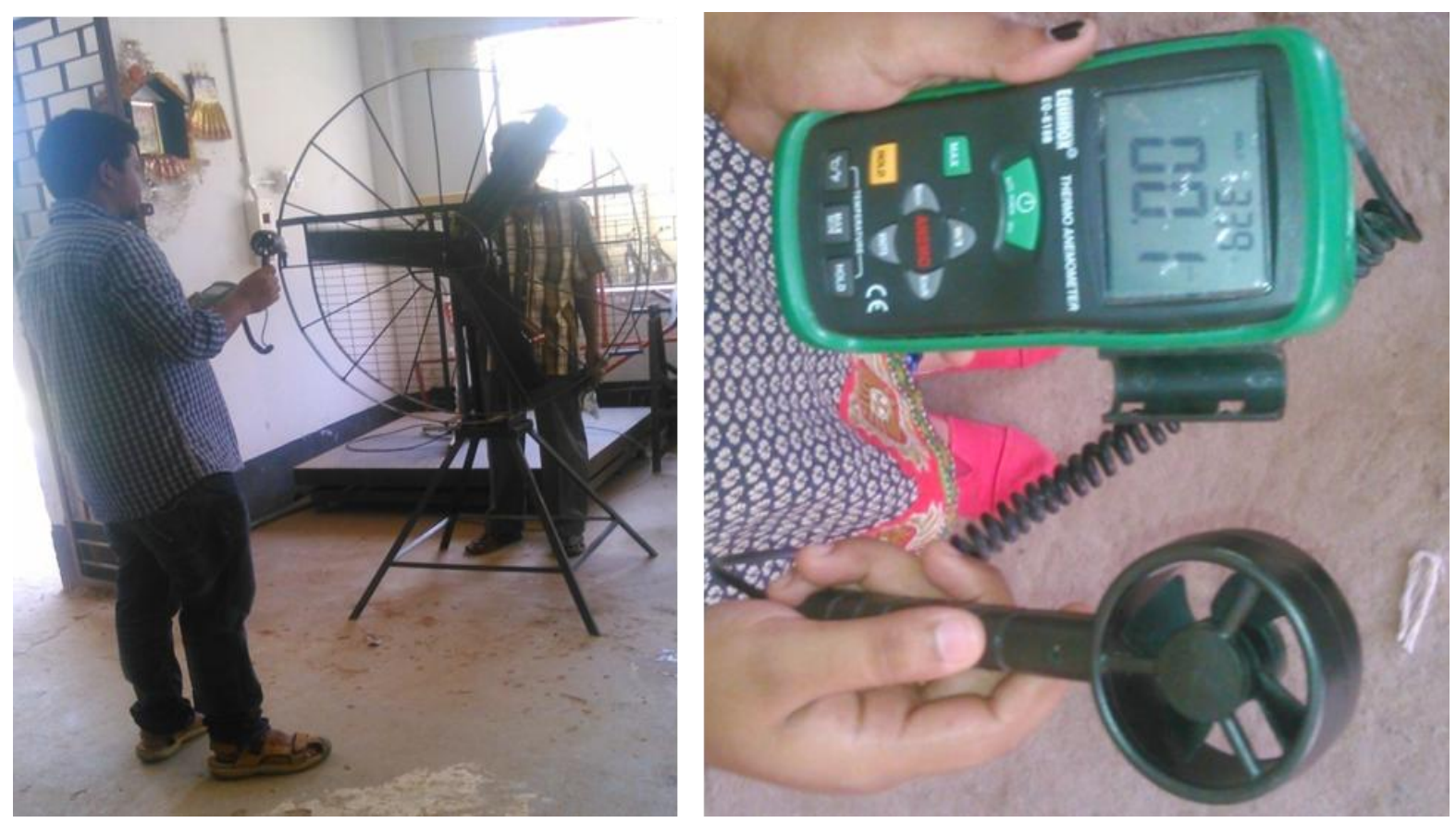
Fig.6 Measurement of heart rate using pulse oximeter

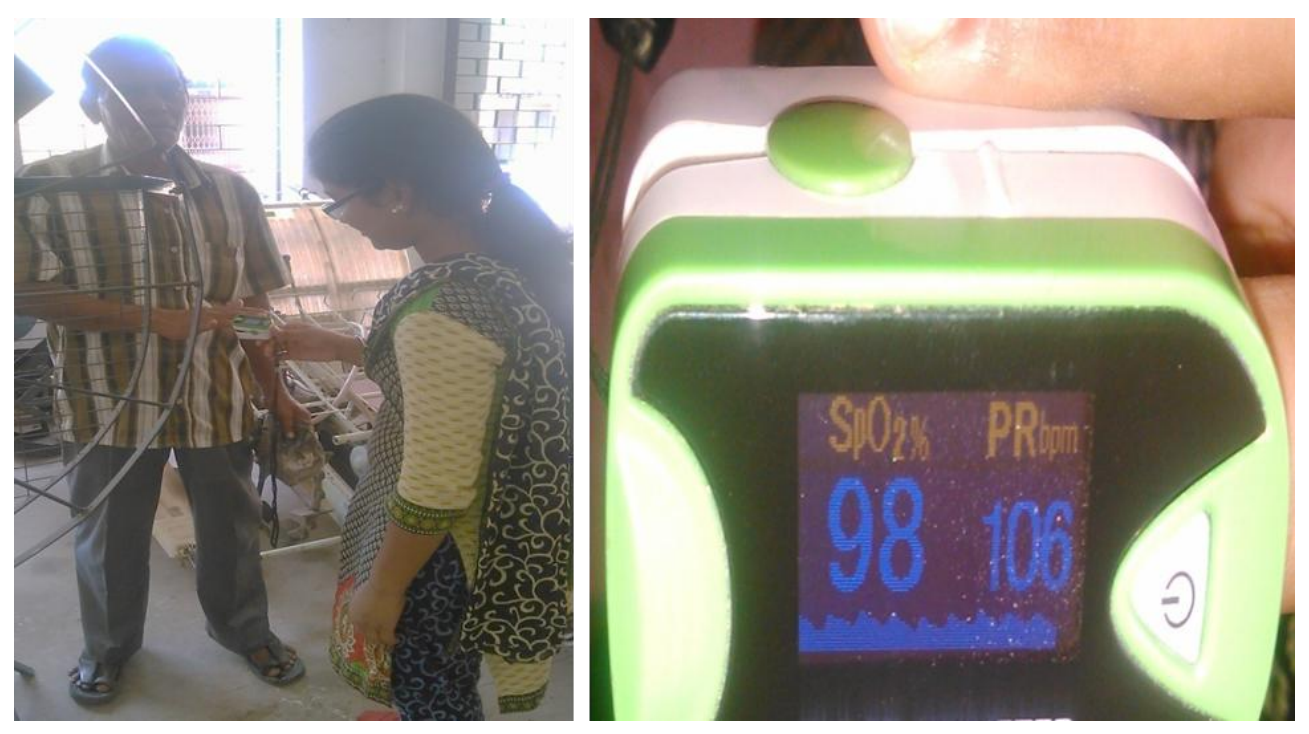

Fig.7 Variation of wind speed with different worker groups and different types of winnowers

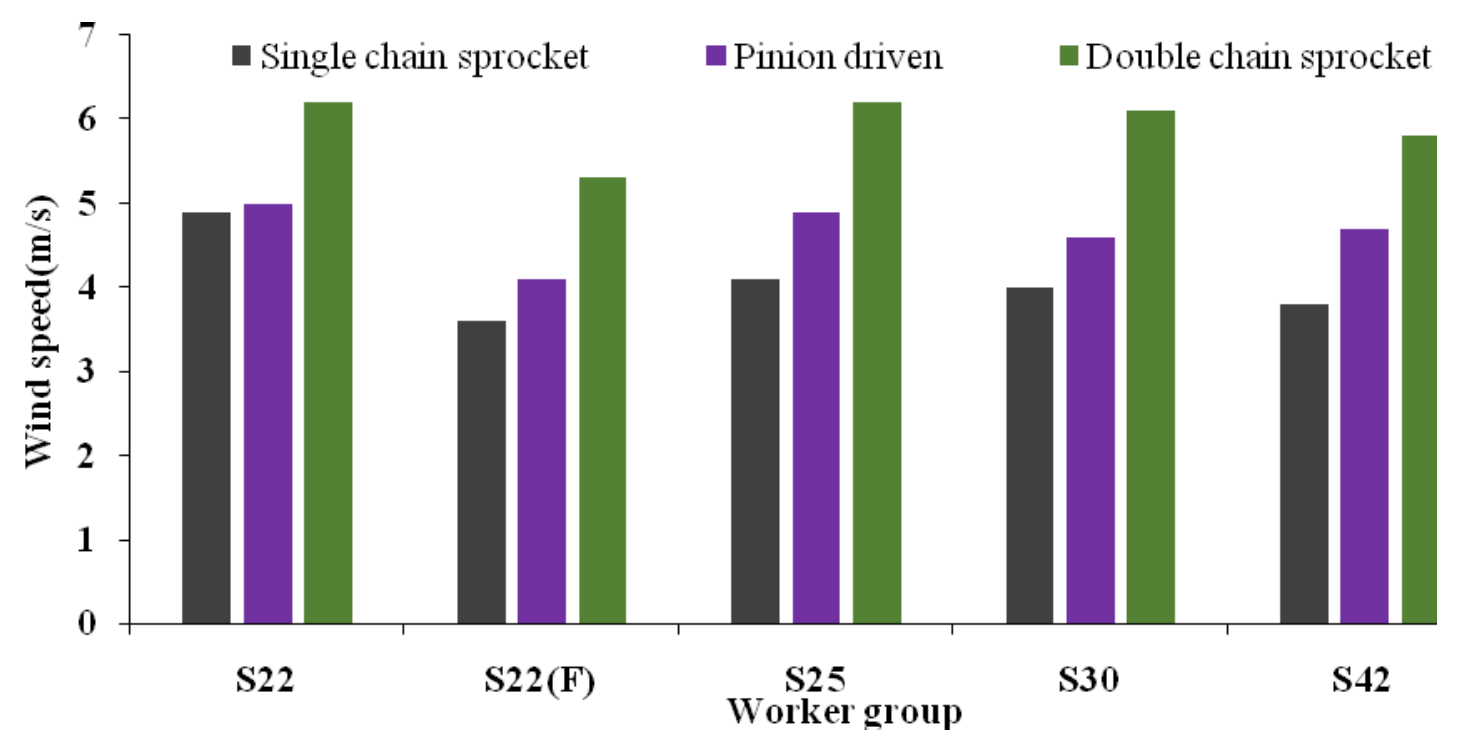


Int.J.Curr.Microbiol.App.Sci (2020) 9(3): 871-879

Table.1 Ergonomical evaluation of three different types of winnowers

\begin{tabular}{|c|c|c|c|c|c|c|c|c|c|c|c|c|c|c|c|c|c|}
\hline \multirow{2}{*}{$\begin{array}{l}\text { Work } \\
\text { group }\end{array}$} & \multirow[t]{2}{*}{ HR $_{\text {MAX }}$} & \multirow[t]{2}{*}{ HR $_{\text {REST }}$} & \multicolumn{5}{|c|}{ Pinion drive } & \multicolumn{5}{|c|}{ Single chain sprocket } & \multicolumn{5}{|c|}{ Double chain sprocket } \\
\hline & & & HR $_{\text {WORK }}$ & $\Delta \mathrm{HR}$ & \% HR $_{\text {MAX }}$ & $\mathrm{VO}_{2}$ & $\begin{array}{c}\text { Energy } \\
\text { expenditure }\end{array}$ & HR WORK & $\Delta \mathrm{HR}$ & $\% \mathrm{HR}_{\mathrm{MAX}}$ & $\mathbf{V O}_{2}$ & $\begin{array}{c}\text { Energy } \\
\text { expenditure }\end{array}$ & HR $_{\text {WORK }}$ & $\Delta \mathrm{HR}$ & $\% \mathrm{HR}_{\text {MAX }}$ & $\mathrm{VO}_{2}$ & $\begin{array}{c}\text { Energy } \\
\text { expenditure }\end{array}$ \\
\hline $\mathbf{S}_{22}$ & 198 & 77 & 135 & 58 & 68.18 & 0.87 & 18.16 & 128 & 51 & 64.65 & 0.76 & 15.89 & 120 & 43 & 60.61 & 0.64 & 13.29 \\
\hline $\mathbf{S}_{22}(\mathrm{~F})$ & 198 & 69 & 137 & 68 & 69.19 & 0.90 & 18.81 & 132 & 63 & 66.67 & 0.82 & 17.19 & 125 & 56 & 63.13 & 0.71 & 14.92 \\
\hline $\mathbf{S}_{25}$ & 195 & 79 & 132 & 53 & 67.69 & 0.82 & 17.19 & 127 & 48 & 65.13 & 0.74 & 15.57 & 119 & 40 & 61.03 & 0.62 & 12.97 \\
\hline $\mathbf{S}_{30}$ & 186 & 76 & 130 & 54 & 69.89 & 0.79 & 16.54 & 127 & 51 & 68.28 & 0.74 & 15.57 & 119 & 43 & 63.98 & 0.62 & 12.97 \\
\hline $\mathbf{S}_{42}$ & 178 & 71 & 129 & 58 & 72.47 & 0.77 & 16.21 & 124 & 53 & 69.66 & 0.70 & 14.59 & 116 & 45 & 65.17 & 0.57 & 12.00 \\
\hline
\end{tabular}

Note: HR means Heat rate in beats/min., $\mathrm{VO}_{2}$ means oxygen consumption in 1/min., Energy expenditure in $\mathrm{kJ} / \mathrm{min}$. 
Conclusion of the study are as follows

The developed winnower with a double chain and sprocket mechanism produced an average wind speed of $5.92 \mathrm{~m} / \mathrm{s}$ which can efficiently remove the straw from grain for both paddy and wheat.

It required less energy (avg. energy expenditure of $13.23 \mathrm{~kJ} / \mathrm{min}$.) for carrying out winnowing operation which would help the farm workers especially the women workers to operate this winnower with less drudgery.

The overall weight of the machine was only $23.5 \mathrm{~kg}$ which make it suitable for transportation.

The production cost of the double chain sprocket winnower was 4492 rupees making it affordable for small and marginal farmers.

\section{Acknowledgement}

The authors would like to thank the HOD of Farm Machinery and Power Department, College of Agricultural Engineering and Technology, Bhubaneswar, Odisha and DE of OFMRDC (Odisha Farm Machinery Research and Development Centre), Bhubaneswar for providing financial and technical support to carry out the project.

\section{References}

Anonymous 2020. https://www.mordorintelligence.com/in dustry-reports/india-rice-market

Anonymous 2020a. https://www.statista.com/statistics/7642 99/india-yield-of-rice/

Anonymous. 2015. National Rice Research Institute. Cuttack, Odisha.www.nrri.nc.in

Anonymous. 2019. State agricultural plan of Odisha. OUAT; 38-39.

Bilanski, W.K. and Lai, R., 1965. Behavior of threshed materials in a vertical wind tunnel. Transactions of the ASAE, 8(3), pp.411-0413.

Fox, S. M. III., Naughton, J. P., and Haskell, W. L., 1971. Physical activity and the prevention of coronary heart disease. Ann. Clin. Res. 3, 404-432

Gorial, B.Y. and O'callaghan, J.R., 1990. Aerodynamic properties of grain/straw materials. Journal of Agricultural Engineering Research, 46, pp.275-290.

Park, S.J. and Kim, M.H., 1998. Some physical properties of chopped rice straw. J. Korean Soc. Agric. Machin, 23, pp.583-590.

Singh, S. P. and Gite, L. P., 2007. Ergonomic evaluation of a hand operated paddy winnower by women workers. J. Agri. Eng., 44:67-71.

\section{How to cite this article:}

Anup Behera, Arjya Utkalini Sahoo, Jyoti Ranjan Swain, Suprava Kar and Markandeya Mahapatra. 2020. Development and Evaluation of a Hand Operated Double Chain-Sprocket Winnower for Cereal Crops. Int.J.Curr.Microbiol.App.Sci. 9(03): 871-879. doi: https://doi.org/10.20546/ijcmas.2020.903.102 